\title{
COMPETITIVENESS OF RURAL AREAS DUE TO DEVELOPMENT OF ORGANIC AGRICULTURE
}

\author{
E.G. Kovalenko \\ Federal State Budgetary Educational Institution of Higher \\ Education «National Research Ogarev Mordovia State \\ University» \\ «National Research Ogarev Mordovia State University, \\ MRSU \\ Bolshevistskaya Street 68, Saransk, 430005, Russia; \\ kovelena13@mail.ru \\ O.Yu. Yakimova \\ Federal State Budgetary Educational Institution of Higher \\ Education «National Research Ogarev Mordovia State \\ University» \\ «National Research Ogarev Mordovia State University, \\ MRSU \\ Bolshevistskaya Street 68, Saransk, 430005, Russia; \\ olyakimova@yandex.ru
}

\author{
T.M. Polushkina \\ Federal State Budgetary Educational Institution of Higher \\ Education «National Research Ogarev Mordovia State \\ University» \\ «National Research Ogarev Mordovia State University, \\ MRSU \\ Bolshevistskaya Street 68, Saransk, 430005, Russia \\ polushkinatm@gmail.com
}

\section{I.I. Igaikina}

Federal State Budgetary Educational Institution of Higher Education «National Research Ogarev Mordovia State University»

«National Research Ogarev Mordovia State University, MRSU

Bolshevistskaya Street 68, Saransk, 430005, Russia; igaikinamgu@mail.ru 
the population with quality food. Possessing a rich potential (natural, historical and cultural and other), rural territories fulfill numerous national economic functions. However, their crisis status is recorded practically throughout the country, which leads to the migration of villagers to the cities, the disappearance of thousands of villages and hamlets from the map of the country. These are mostly small settlements with a population of up to $300-500$ inhabitants located on the periphery, in which small-scale farming predominate (farms, personal part-time farms) and which in many countries are the basis for the development of organic agriculture, provided that the necessary institutional environment is presented. Thus, a comprehensive solution to the problems of rural areas sustainable development and increasing their competitiveness through organic agriculture should become a priority direction of the state agrarian policy.

\section{MATERIALS AND METHOD}

The working hypothesis of the study is organic agriculture (OA) concept formation in Russia, developing proposals of leading Russian agricultural scientists such as Altukhov A.I. (2013), Nechaev V.I. (2013), Porfiryev B.N. (2013), Sokolova Z.E. (2013), Mikhailushkin P.V. (2013), Taran V.V. (2013), Zakrevsky V.V. (2011), Repeshov SM (2011), Kundius VA (2015), VoronkovaO.Yu. (2015). They substantiated the need to adopt a general concept for the development of organic agriculture products market and necessary federal laws, as well as providing financial, information and marketing support to the producers of organic products. For example, one can see the support of organic agriculture in the framework of the Common Agricultural Policy of the European Union, which is implemented in the form of direct payments for 1 hectare to producers from the EU budget and indirect support measures in the form of assisting in certification, providing information and consulting services, financing research and environmental protection activities co-financed from the EU budget and selected countries.

The main direction of the study is the substantiation of legal, institutional and financial conditions for the organic agriculture sector formation in Russia at the state, regional and local levels in conjunction with measures of state support for the sustainable development of rural areas of the country.

The study was conducted based on the information from the Federal State Statistics Service, program documents, analytical reports and reports of the Ministry of Agriculture of the Russian Federation, the Union of Organic Agriculture of Russia, Euromonitor International, Organic Monitor, FiBL. The database on organic production and organic products market has been processed using statistical methods. Such approach gave us opportunity to determine the differentiation of the countries of the world in terms of the level of organic agriculture development, clarify the main trends and patterns in this segment of economy, and determine the place and role of Russia nowadays and in the future.

\section{RESULTS AND DISCUSSION}

The main goal of any modern state policy is to create conditions that ensure a decent life for citizens, whose primary need are foodstuffs, their accessibility and quality. Medical studies of the influence of various factors on human health have shown that it is affected by $50-55 \%$ of food quality. According to the rating of the health and well-being of the nation, compiled by medical journal The Lancet on the basis of the UN's 2015 sustainable development goals (SDG), Russia took the 119th place (54 points out of 100 maximum possible), falling behind the leaders (Iceland, Singapore and Sweden) by 31 points. In Russia, the annual economic damage from diseases associated with malnutrition $(30-50 \%$ of all diseases) is almost 13 trillion rubles. The number of these diseases can be reduced by providing the population with a healthy diet. The solution to this problem consists of two components: the formation of a healthy lifestyle and healthy eating habits among Russians (the demand for ecological products); ensuring environmental food production and quality control system. Both directions are at the initial stage of formation because there is some kind of request to solve this problem both in society and in the real economy. This article focuses on the second direction, i.e. on organic agriculture as a source of quality ecological products.

Organic agriculture is one of the most rapidly developing sectors of economy. Its parameters can be described by the areas of organic land, number of organic producers, and volume of the market for organically produced products. According to the studies of FiBL (the Research Institute of Organic Agriculture, Switzerland) and IFOAM published in February 2016, organic agriculture is developing: while data on this field in 1999 were available only in 77 countries. In 2014, they were available already in 172 countries, i.e. it was a 2.2-time growth. The total area of organic farmland in 2014 amounted to 43.7 million ha (1\% of all farmland), which is 0.5 million hectares more than in 2013. As can be seen in Figure 1 , the area of organic land in the world has almost quadrupled since 1999. Organic farmland is distributed across the continents as follows: $7.1 \%$ in North America, 15.6\% in South America, 26.6\% in Europe, $8.2 \%$ in Asia, 1.3\% in Africa and $39.6 \%$ in Oceania.

Top 10 countries with the largest areas of organic farmland include Australia (17.2 million hectares), Argentina (3.1 million hectares), the USA (2.2 million hectares), China (1.9 million hectares), Spain (1.7 million hectares), Italy (1.4 million hectares), Uruguay (1.3 million hectares), France (1.1 million hectares), Germany (1.0 million hectares) $\mathrm{Ha}$ ) and Canada (0.9 million hectares).

11 countries have more than $10 \%$ of organic agricultural land: the Falkland Islands (Malvinas) $(36.3 \%)$, Liechtenstein (30.9\%), Austria (19.4\%), Sweden (16.4\%), Estonia (16.2\%), Samoa (14.3\%), Switzerland (12.7\%), Sao Tome and Principe $(12.0 \%)$, Latvia (11.2\%), the Czech Republic (11.1\%) and Italy $(10.8 \%)$.

Organic agriculture is one of the types of agriculture, which is an alternative to the classical industrialization scheme and competes with it in the world agro-food market. It is obvious that in the coming years the development of agriculture in Russia solely by the organic type is impossible for a number of reasons. Insufficient volumes of domestic production of a number of food groups (for example, dairy 
products, fruits and vegetables), limited financial resources for new large-scale projects, and lack of a "Green growth strategy" in the industry are among them. Nevertheless, under such modern conditions (foreign sanctions, counter-sanctions and import substitution policies), there is a need to search for new mobilization opportunities of rural development and domestic resources for quality and affordable food production. In recent years, the growth of agricultural production in the country is provided by agricultural organizations, whose share in the total volume in 2015 was $51.5 \%$. According to the Federal State Statistics Service, the number of large and medium-sized agricultural organizations from 2005 to 2015 declined 3.3 times due to liquidation and absorption. As a result of these processes, in hundreds of rural settlements there is no employer organization. There is a great tension in the labor market, since the employment opportunities and the selection of vacancies in rural areas are severely limited. Obviously, under these conditions, for most rural settlements, especially those located on the periphery of large cities, the possibility of survival is associated with the development of small business, including organic agriculture. This is a chance for small-scale farms to significantly strengthen their positions in agro-industrial complex and increase the efficiency of their activities, since they are non-competitive with large organizations, significantly losing them in the scale of production and production costs. Producing organic products without the use of mineral fertilizers, pesticides, growth regulators, genetically modified organisms and replacing them with an increase in the number of mechanical operations, biological means of protection, etc., farmers will be able to sell them at higher prices (by $30-200 \%$ depending on products type) due to higher quality products. Under such conditions, small production volumes will become more profitable. The evidences are given by the UN FAO studies, according to which in the organization of organic production on small-scale farms the productivity increased by $116 \%$, farmers' incomes increased $2-3$ times [1].

At the state level, the problem of rural areas sustainability in Russia is carried out through civil housing construction and industrial infrastructure development. However, the necessary level of social comfort for rural population cannot be achieved and the negative processes continue. The tasks of forming the organic agriculture system are solved solely, and initiated only by the Union of Organic Agriculture of Russia and a number of companies that are counting on occupying the domestic emerging market of ecological products and a niche of rapidly growing demand in a number of foreign countries. In our opinion, these two tasks can and should be decided in our country in a complex. Since without additional opportunities for economic development of rural areas, increasing their competitiveness, it is unlikely to solve social problems.

Sustainable development of rural areas is a relatively new direction for Russian science, which is developing in accordance with the decisions formulated by the UN International Commission on Environment and Development in the report "Our Common Future" [2], as well as the approaches developed by the international community to formulate and implement the policy of rural development. Food and Agriculture Organization (FAO) uses a system of methods to ensure the economic and social development of rural areas, food security, conservation of natural resources and environmental protection, including administrative and legal, organizational, economic and socio-psychological methods, for example, education and advertising [3].

In Russia, according to the Strategy for Sustainable Development of Rural Territories of the Russian Federation for the period until 2030, the main emphasis is on developing the social and economic sphere of rural areas, but the problems of environmental balance and security are not emphasized [4]. Taking into account the multidimensionality of this scientific direction, geographers, economists, historians and other scientists are engaged in its research. For example, features, trends and factors of spatial changes in rural areas are explored by economists-geographers T.G. Nefedova (2013), A.I.Treivish (2010), V.V. Patitsiorkovsky (2010), I.A. Semina and L V. Sotova (2014). The problems of social and economic development of rural areas, directions and instruments of state support are presented in the studies of I.V. Antohonova (2009), R H. Adukov and A.N. Adukova (2011), L.V. Bondarenko (2014), F. Mantino (2010), I.N. Merenkova (2011), A.V. Merzlova, (2012), I.V. Mishchenko (2012), I.V. Palatkin (2008), A. Ya. Trotskovsky (1997).

The complexity of the research problem, the large differentiation of rural areas by location, the level of development and available potential, the lack of methodology and practical recommendations for managing the socioeconomic development of the village makes scientists to conduct further research, including ensuring the competitiveness of peripheral rural areas, which are in a crisis situation. In our opinion, the development of organic agriculture is one of the directions for strengthening the economy of such territories, based on the traditions of farming in personal part-time farms, which ensure the preservation of the environment. In Russia, organic farming has long history in agricultural science. It was founded by well-known agricultural scientists A.T. Bolotov (1952), V.R. Williams (1949), V.V. Dokuchaev (1949), T.S. Maltsev (1955), V.V. Fokin and etc.

The concept of "organic farming" was introduced by Lord Northbourne (1940) in the book "Look to the land", written under the influence of the system of biodynamic agriculture of R. Steiner (1924). Among the founders of organic agriculture are A. Howard (1940) and E. Balfour (1939), whose works were devoted to the negative effect of chemical fertilizers on the health of animals and plants and the development of practical proposals for organic farming. A major contribution to the development of this branch of agriculture - in spite of the main trend of its intensification with the use of chemicals and GMO - was made by M. Fukuoka, B. Böck, M. Kleinmann, S. Lang, N. Prokopchik, J. Paul, T. Richter, Hilfaker, et al. (A.A. Veko, A.V. Ravino, 2016).

In Russia, this trend is developing rather slowly at present. The problems of organic farming are studied by such scientists as A.I. Altukhov, O.A. Kozlova, V.M. Koshelev, A.G. Paptsov, A.V. Peshkova, A.V. Petrikov, J.E. Sokolova I.G. Ushachev, N.S. Kharitonov, A.V. Hodus, A.V. Yablokov and others. Numerous problems and mechanisms of organic 
agriculture development in the country have not been sufficiently studied. The environmental and social benefits of organic agriculture are obvious, because its very essence is to preserve the environment (ecological compatibility) and improve the quality of life (through a healthy diet). But its economic efficiency is not so unambiguous. This is due to the technological features of organic production. There are some of them: the increase in production costs due to the increase in manual labour; the abandonment of mineral fertilizers and pesticides, growth regulators and feed additives; certification costs; the search for marketing channels; advertising; products promotion associated with a higher price for organic products. These problems require research and development of methodological recommendations for state and municipal government bodies, farmers and population. According to the US National Organic Council on Standards, organic farming is an ecological production management system that maintains and enhances biological diversity, biological cycles and soil biological activity. This is based on the minimal use of offfarm investments and on management methods that restore, maintain and enhance environmental harmony. In accordance with FAO terminology, the organic farming is an integrated production management system that stimulates and enhances the well-being of the agrarian ecosystem, including biological diversity, biological cycles and soil biological activity. All of these are achieved using all possible agronomic, biological and mechanical methods as opposed to using synthetic materials to perform specific functions within the system [5].

Thus, organic agriculture, relying on ecological processes, biodiversity and natural cycles, which are specific to local conditions and avoiding resources, the use of which is associated with negative effects, has a number of undeniable advantages over the traditional one. Among them: long-term stability, soil structure improvement, biodiversity increasing, safety for human and animal health, as well as more tasteful foodstuff. Organic agriculture unites traditions, innovations and science in order to improve the state of environment and develop a fair relationship of a high quality of life for all people involved in it.

Back in 2005, the General Assembly of the International Federation of Organic Agriculture Movements (IFOAM) in Adelaide (Australia) adopted the basic principles of organic agriculture $[6,7]$. The first of these is the principle of health, which implies that organic agriculture must maintain and improve the healthy state of the soil, plant, animal, human and planet as a single and indivisible whole. The second principle is ecological. It suggests that organic agriculture should be based on the principles of existence of natural ecological systems and natural cycles, working and coexisting with them and supporting them. The third principle is principle of justice. According to it organic agriculture should serve as a guarantee of the fairness of relations between people and taking into account the environment and life opportunities. The fifth principle of concern for future generations proclaims that the management of organic agriculture must be preventive and responsible in order to protect the health and well-being of present and future generations and environment [5].

It is worth noting that the transition to organic farming does not mean simplification of production, does not exclude the use of integrated approach to the solution of tasks with the use of modern methods and tools, but only introduces restrictions on the use of mineral fertilizers, pesticides, herbicides, GMOs and other means, the use of which, in fact, harms nature and human health as a part of it.

As is known, from a position of sustainable development, agriculture passes through several stages of development, characterized by social, economic or environmental specification. The first stage is connected with overcoming the problem of hunger or ensuring food security. It is typical for countries of socially oriented agriculture. The next stage is typical for countries of economically oriented agriculture, where the main efforts are aimed at solving the problems of the low level of well-being of those employed in the agrarian sector. Finally, the countries with environmentally oriented agriculture solve the problem of minimizing environmental pollution resulting from agrarian activities [8]. It is obvious that in the long term there is no alternative to organic agriculture development, because industrial farming ultimately leads to the destruction of natural environment, which is the fundamental basis of agrarian economy, and the whole lifesupport system for humankind. Organic agriculture has a number of possible limitations. For example, due to lower productivity in organic farms against industrial ones, it is more difficult to solve the problem of poverty and hunger in the world (805 million people are starving or every nine inhabitants of the planet). As for Russia, its food security is not fully ensured; therefore, a complete transition to the production of organic products is not yet possible. However, the growing significant demand for organic products in the world food market (over the past 14 years their sales have increased almost fivefold, and demand grew by $3 \%$ only in 2015 , while sales of inorganic products fell by $1.2 \%$ ) shows the need to use organic principles of management in highquality food production $[1,9]$.

For the development of organic agriculture in Russia, there are objective conditions, among which the availability of the main resource. It is about 40 million hectares of arable land that were derived from rotation in recent decades. All over the world, such lands are scarce. Furthermore, the number of mineral used fertilizers in Russia is ten times less than in many countries of the world (for example, compared with the United States, it is 11 times less, with China - 23 times) [1]. Organic agriculture can become one of the potential growth points for rural settlements as indicated in the Strategy for Sustainable Development of the Russian Federation for the period up to 2030.

Taking into account that almost $40 \%$ of agricultural production in the country is produced in personal part-time farms with observance of some organic principles of management, the production of ecological products can be extremely important for raising incomes level of rural workers (the ratio of wages in agriculture to the average Russian level is $52.2 \%$, the difference in per capita disposable resources in rural and urban households has increased 11.6 times by 2015). Because of these reasons, hundreds of settlements disappear every year from the map of the country [10]. At the same time, rural settlements account for more than $80 \%$ of the total number of municipalities in the country, being the main form 
of territorial organization of local self-government. Under such conditions, it is necessary to search for new effective ways for their development and the state should create motivating mechanisms for self-development of rural territories with the purpose of increasing their competitiveness, including stimulation of organic farming development.

Improving of environmental situation in regions due to the refusing to application of fertilizers, pesticides and other chemicals will also contribute to quality of life and health of Russians. At present, about $1 / 3$ of the total pollution of nature falls on the agrarian sector of the economy. Annual economic losses from intensive agriculture in Russia exceed 3 billion rubles. Organic agriculture can reduce the amount of energy consumed by 1 hectare of cultivated land by almost 3 times (mainly by eliminating the use of mineral fertilizers, synthetic pesticides, using local feed and processing products), which will lead to a significant reduction in greenhouse gases emissions [11]. Organic agriculture for modern Russia can also be considered as one of the elements of innovative development, since food market begins to offer products with new consumer properties, so useful to humans.

Justifying the concept of organic agriculture development to improve the competitiveness of peripheral rural areas, we can distinguish three groups of factors that determine its strategic advantages.

The first group is economic benefits, namely: strengthening of Russia's economic position in the global food market and increasing the competitiveness of Russian agricultural products; obtaining a new sphere of influence; increase in the GDP of the Russian Federation due to the legalization of domestic organic products; increase of small forms of farming, which have adopted the standards of organic agriculture; improvement of the international image and investment climate in Russia due to the development of "green economy". If at least $5 \%$ of agricultural producers can officially join the organic agriculture sector with high added value, then it can give a GDP growth of tens of billions of rubles. In the meantime, the Russian organic market is dominated by import products, which are often produced from Russian raw materials. Organic agriculture can contribute to the development of small and medium-sized businesses in rural areas, creation and promotion of regional quality brands, which will promote investment inflow to rural areas.

The second group is social benefits: organic agriculture unites traditions, innovations and science, promotes the development of fair relations and high quality of life for rural people; provides an increase in food nutritional value, improvement of foodstuff quality for population, protection of interests of those who, due to their health or other reasons, are forced to eat ecologically clean food (pregnant, lactating mothers, children, allergies (30\% of the population of the Russian Federation). The increase in the level and quality of life in countryside and, as a result, the increase in the sustainability of rural areas development, will lead to a decrease in the outflow of population from villages and the stimulation of specialists' migration to rural communities.
The third group is environmental benefits: soils protection and conservation from erosion, desertification, salinization; protection of water resources, soil, air from pollution by chemicals; increasing biodiversity; reduction of energy consumption per 1 hectare of cultivated land; reduction of greenhouse gas emissions and fresh water consumption in agricultural production in comparison with intensive agriculture, etc. [11].

For small forms of farming, which, under conditions of Russia's membership in the WTO, cannot compete with large producers, production of organic products can be some kind of opportunity that allows them not just to survive, but compete fully with large companies due to the high quality of products. Another important fact is that very often-organic farming is situated on the lands of risky agriculture, where industrial agriculture is unprofitable. The world's thirty-year practice has proved that organic agriculture can develop in depressed regions, provided favorable ecology. According to the UN studies, the productivity of small forms of agriculture increased by $116 \%$, and farmers' incomes increased by 2-3 times with farms reorganization and organic production methods introduction. Production processes are independent of the supply of fertilizers, pesticides, herbicides, antibiotics, growth hormones, etc. allowed to ensure greater stability of farms from external economic factors. The increase in villagers' incomes as well assoil preservation creates favorable conditions for the sustainable development of rural areas [11].

The concept of organic agricultural production in Russia, which is at the initial stage of development, includes the creation of legal, institutional and financial systems at the federal, regional and local levels.

At the federal level, it is necessary: 1) to create a legal basis for organic agriculture, including laws (with the necessary changes to the current legislation), national standards and technical regulations for products; 2) to provide state support through budgetary payments (grants, compensations), preferential crediting and taxation; 3) to create the system of organizations for certifying and technological control of organic production and its quality with the participation of international organizations and auditors; 4) to organize scientific research and training of personnel in organic agriculture in specialized research institutes, state higher and professional educational institutions. At the regional public administration level, there is: 1) the adoption of regional legislation on organic farming, the establishment of registers of organic commodity producers, the identification of authorized bodies to regulate activities in the field of organic farming. It is necessary to develop and implement programs for the development of organic agriculture, including location and area for organic production, measures and conditions for support. Besides, one should establish accredited certification centers, approve requirements for the production, processing, labeling and trade of organic products. Centers of informatization, consulting and marketing support of organic products must be established. At the regional level, the system of measures includes two groups intended for producers and consumers of organic products. For organic producers, the organization of production in accordance with organic principles, national and international 
standards requires: 1) assessment of conditions: the ecological condition of the farmland, production capacity, markets; 2) development of a business plan for organic production, preparation of documents and application to the certifying organization to confirm the organic status; 3) joining associations (unions), cooperatives of producers of organic products for marketing and sales system optimization, passing certification, receiving services. The system of measures for consumers of organic products includes: 1) information on organic products in the media and popular publications in conjunction with the promotion of a healthy lifestyle; 2) state and municipal procurement for social institutions, children's and therapeutic nutrition; 3) organization of trading system through branded stores, online stores of environmentally friendly products.

In our conviction, the implementation of the above measures system will achieve the goal of improving population life quality through health promotion through nutrition with environmentally friendly and safe products and improving of environment ecology.

It should be noted that the first steps in this direction have already been done. In May 2016, the first fundamental document of the branch was adopted in Russia - The national standard for organic agricultural products. It determines the rules for its production, processing, transportation and storage of organic products and promises new development prospects. The standard completely banned GMOs and became the only State Standard guaranteeing their absence in products [1]. The national standard has been brought into line with regulations on organic agriculture in the EU, but the issue of its recognition abroad, as well as international standards in Russia, will be resolved only after the adoption of the federal law on the limitation of greenhouse gases. The next step towards the development of organic agriculture is the adoption of the Federal Law "On the Production of Organic Products" and on regulation of organic products market.

A complete quality assurance system for organic agriculture products (an organic guarantee system) should be created in the country. This can be provided by a developed system of certification (firstly), and inspection (secondly), which cover the technology of organic production, factors of production and final organic products. This inspection in Europe, for example, is carried out by well-known inspection and (or) organic certification organizations, in particular: Soil Association (UK), Organic Farmers and Growers (UK), SKAL (Netherlands), KRAV (Sweden), Agencebio (France), Demeter International (Germany and German-speaking countries), Bioland (Germany), BIOHELLAS (Greece), DIO (Greece), Irish Organic Farmers and Soil Association (Ireland), Association sans but lucrative - ASBL (Belgium). Similar organization should be created in the Russian Federation [12]. The competence of this kind of service should include the entire process of organic products commodity circulation to the consumer. Among them: development of organic standards, the certification of controlling organizations, as well as inspection for compliance with organic standards. Manufacturers of organic products must adequately support the production cycle before they can sell their products as organic ones. Moreover, inspections (according to EU experience) should be conducted at least once a year for full compliance with all the rules established by law. The quality of soils, the conditions of animals keeping, various parameters of fields' conditions, perennial plantations, pasturelands, greenhouses, warehouses, etc., must be checked.

Producers should be motivated by the state to conscientiously implement all the "rules of the game" in the market of organic products. Only in this case it is possible to wait for consumers growing demand of eco-products. In general, the role of the state in the development of organic agriculture should not be limited only to certification and inspection activities. It would be advisable to provide compensation for certification cost of product already at the stage of passing certification. Further, producers who have received "organic" status, especially in the first stages of development, should be granted tax and other financial preferences. There should be direct subsidization for organic production activity that has undoubted advantage for society, both from an ecological and a social point of view, also as a factor of diversification of food market, opening up new opportunities for entrepreneurship and providing consumers with more diverse foodstuff. It is necessary to introduce a number of amendments to the State Program for Agriculture Development until 2020, especially with regard to direct support. Subsidies for organic products should be much higher [13]. In addition, support for organic production development can be considered as environmental protection measures (refer to the "green" basket), in particular, to restore and improve soil fertility $[14,15]$. As a very important direction of support, one should consider the organization of education aimed at organic agriculture (it is advisable to establish special educational centers on the basis of higher educational institutions). In addition, an extensive informational system of support for beginning "eco-producers" and advertising of organic foodstuff consumption should be created at the state level. In accordance with the Federal Law "On the Production of Organic Products", the Federal Law "On Environmental Protection", the Government Decree "On Approving the Concept of Long-Term Social and Economic Development of the Russian Federation up to 2020", and Government Decree "On the Approval of the Strategy for Sustainable Development Rural territories of the Russian Federation until 2030", a concept of organic agriculture development, based on the social and environmental significance of organic farming methods, should be developed.

\section{Acknowledgment}

The authors are grateful to Erasmus+ fund that has provided the financial support for the research in the form of the grant to Jean Monnet Module "Organic farming in the system of sustainable rural development: the EU experience", 2016 - 2019 (project No. 575610-EPP-1-2016-1-RUEPPJMO-MODULE).

\section{References}

[1] Materials of the XVII International agro-industrial exhibition "Golden autumn" in the framework of the discussion on the theme: "Organic 
agriculture: a new point of economic growth", 2015. URL: http://agroday.ru/gosnews/zelenaja_yekonomika.

[2] Report of the World Commission on Environment and Development: Our Common Future (2008). Transmitted to the General Assembly as an Annex to document A/42/427 - Development and International Co-operation: Environment. URL: http://www.un-documents.net/wced-ocf.htm.

[3] J. B. Hardaker,. "Guidelines for the integration of sustainable agriculture and rural development into agricultural policies", 1997, Rome, FAO. URL: http://www.fao.org/docrep/w7541e/w7541e00.htm\#Contents.

[4] Strategy for sustainable development of rural territories of the Russian Federation for the period till 2030, URL: http://mcxconsult.ru/d/77622/d/strategiya_razvitiya_selskikh_territoriy_rf_do_203 0 goda.pdf

[5] A. I. Altukhov, V. I. Nechaev, B. N. Wall, "The "Green" agricultural economy" M. : Publishing house of Russian state agrarian University, MTAA, 2013, 104 p.

[6] Zh. E. Sokolova, "Development of world market of products of organic agriculture". Moscow, 2013. URL: http://economy-lib.com/razvitiemirovogo-rynka-produktsii-organicheskogo-selskogo-hozyaystva

[7] S. Padel, H. Röcklinsberg, O. Schmid, "The implementation of organic principles and values in the European Regulation for organic food", Food policy, 34, pp. 245 - 251, 2009.
[8] T. N. Nefedova, "Rural Russia at the crossroads: geographical essays". Moscow: New publishing house, 2003, pp. $22-23$.

[9] R.B. Tranter, R.M. Bennett, L. Costa, C. Cowan, G.C. Holt, P.J. Jones, M. Miele, M. Sottomayor, J. Vestergaard, 'Consumers' willingness-topay for organic conversion-grade food: Evidence from five EU countries". Food Policy, Vol. 34, Issue 3, pp. 287 - 294, June 2009.

[10] The report on sustainable development of rural territories of the Russian Federation, 2014. URL: http://sozrf.ru/gossovet_21_04/

[11] Russia's prospects in organic. URL: http://sozrf.ru/perspektiva-k-2020/

[12] A. Y.Egorov, "The Formation and development of the market for organic agricultural products: the example of the Central Federal district". Voronezh, 2014, 233 p.

[13] T. M. Polushkina and Y. S. Panchina "Organic agriculture to green economy", $2015 . \quad$ URL: http://uecs.ru/index.php?option=com_flexicontent\&view=items\&id=357 5:2015-06-18-07-11-32.

[14] A. V. Peshkova, "Economic preconditions for the development of organic agriculture in the regions of Russia", International agricultural journal, vol. 1, pp. $62-64,2012$.

[15] T. M. Polushkina, "Organic agriculture in the sustainable development of rural areas", Problems of the theory and practice of management. The international journal of, vol. 3, pp. 133 - 142, 2016. 